\title{
ANALISIS PERHITUNGAN PENYUSUTAN AKTIVA TETAP MENURUT STANDAR AKUNTANSI KEUANGAN DAN PERATURAN PERPAJAKAN PADA CV. SAMIA SEJAHTERA
}

\author{
Faneisya Pesak $^{1}$, Harijanto Sabijono ${ }^{2}$, Natalia Gerungai ${ }^{3}$ \\ ${ }^{1,2,3}$ Jurusan Akuntansi, Fakultas Ekonomi dan Bisnis, Universitas Sam Ratulangi, Jl. Kampus Bahu, Manado, \\ 95115, Indonesia \\ E-mail : faneisyapesak@gmail.com
}

\begin{abstract}
In calculating depreciation of fixed assets may use depreciation method in accordance with financial accounting standards and tax regulations. Differences in recognition of depreciation expense will result in fiscal correction. The purpose of this study was conducted to find out how the application depreciations of methods of fixed assets according to tax regulations and financial accounting standards, as well as the impact of comparative calculations. The analytical method used is descriptive analysis method. The results show that the company has calculated depreciation expense in accordance with financial accounting standards, but there are still errors in the calculation of depreciation, and the company itself has not done the calculations in accordance with tax regulations. Any difference in depreciation expense according to financial accounting standards and tax laws will result in a positive fiscal correction resulting in the reduction of costs recognized in the commercial income statement. With the reduction of the recognition of these costs can have an impact on the addition of Income Tax (PPh). Value of PPh CV. Samia Sejahtera 2017 Rp18.323.750,00 while the value of PPh CV. Samia Sejahtera by fiscal Rp28.940.000,00 so there is a difference of Rp10.616.250,00.
\end{abstract}

Keywords : Depreciation, Fixed Assets.

\section{PENDAHULUAN}

Perusahaan pada umumnya memiliki tujuan utama yaitu mendapat suatu laba yang maksimal. Untuk mencapai tujuan tersebut perusahaan perlu melakukan pengelolaan yang efektif terhadap keseluruhan aktivitas perusahaan. Bagi perusahaan, pajak merupakan salah satu unsur penting karena pajak yang dianggap sebagai biaya yang dapat mengurangi penerimaan perusahaan. Hal itu memicu perusahaan untuk mencari cara dalam mengurangi biaya pajak yang harus dikeluarkan oleh perusahaan dengan melakukan pengaturan pajak yang harus dibayar. Pembayaran pajak perusahaan dapat diminimalisasikan dengan mengalokasikan atau menyusutkan aktiva yang masih memiliki masa manfaat.

Setiap perusahaan dalam menjalankan kegiatan operasionalnya pasti memiliki aktiva tetap. Aktiva tetap merupakan suatu sarana penunjang terlaksananya kegiatan operasional perusahaan untuk menghasilkan laba atau keuntungan bagi perusahaan. Aktiva tetap yang dimiliki oleh perusahaan seperti bangunan atau gedung sebagai kantor, mesin dan peralatan untuk berproduksi, kendaraan sebagai alat untuk transportasi dan lain-lain sebagai alat yang dapat mendukung semua kegiatan perusahaan. Sehubungan dengan penggunaan aktiva tersebut, maka perusahaan harus mengeluarkan biaya untuk memperoleh maupun menggunakan aktiva. Selain biaya untuk memperoleh dan menggunakan aktiva, perusahaan juga harus mengeluarkan biaya untuk pembayaran kewajiban pajak atas penggunaan aktiva tersebut. Aktiva tetap yang dimiliki perusahaan diharapkan bisa memberikan manfaat bagi perusahaan selama bertahun-tahun. Namun manfaat yang diberikan oleh aktiva tetap semakin lama semakin menurun pemakaiannya, dan menyebabkan terjadinya penyusutan. Penyusutan 
adalah alokasi secara periodik dan sistematis dari harga perolehan aset selama periodeperiode berbeda yang memperoleh manfaat dari penggunaan aset bersangkutan. Dalam melakukan perhitungan penyusutan aktiva tetap dapat menggunakan metode penyusutan yang sesuai standar akuntansi keuangan dan peraturan perpajakan. Metode penyusutan yang digunakan menurut standar akuntansi keuangan adalah untuk menilai kinerja ekonomi perusahaan dan keadaan finansial dari sektor swasta, sedangkan metode penyusutan yang digunakan menurut peraturan perpajakan adalah untuk kepentingan pajak dan harus mengikuti Peraturan Menteri Keuangan Nomor 96/PMK.03/2009.

CV. Samia Sejahtera adalah sebuah perusahaan yang bergerak di bidang manufaktur dalam penjualan Paving Block. Dimana dalam kegiatan operasionalnya CV. Samia Sejahtera menggunakan berbagai jenis aktiva tetap seperti tanah, bangunan, kendaraan, peralatan, dan lain sebagainya yang pastinya akan mengalami penyusutan. Perusahaan telah melakukan perhitungan penyusutan berdasarkan standar akuntansi keuangan hanya saja masih terdapat kekeliruan dalam perhitungan penyusutannya, dan juga perusahaan belum melakukan perhitungan penyusutan aktiva tetap berdasarkan peraturan perpajakan. Untuk itu perlu adanya pembahasan mengenai penerapan perhitungan penyusutan aktiva tetap menurut standar akuntansi keuangan maupun menurut peraturan perpajakan, serta pengaruh perbedaan perhitungan tersebut.

\section{TINJAUAN PUSTAKA}

\subsection{Pengertian Akuntansi}

Menurut Sujarweni (2015:3) menyatakan bahwa akuntansi adalah proses dari transaksi yang dibuktikan dengan faktur, lalu dari transaksi dibuat jurnal, buku besar, neraca lajur, kemudian akan menghasilkan informasi dalam bentuk laporan keuangan yang digunakan pihak-pihak tertentu. Menurut Hery (2017:1) Tujuan akuntansi secara keseluruhan adalah memberikan informasi yang dapat digunakan dalam pengambilan keputusan.

\subsection{Pajak}

Menurut Mardiasmo (2018:3) Definisi pajak menurut Undang-Undang Nomor 16 tahun 2009 tentang perubahan ke empat atas Undang-Undang Nomor 5 tahun 1983 tentang ketentuan Umum dan Tata Cara Perpajakan pada pasal 1 ayat 1 berbunyi pajak adalah kontribusi wajib kepada negara yang terutang oleh orang pribadi atau badan yang bersifat memaksa berdasarkan undang-undang, dengan tidak mendapatkan imbalan secara langsung dan digunakan untuk keperluan negara bagi sebesar-besarnya kemakmuran rakyat.

\subsection{Akuntansi Pajak}

Menurut Agoes dan Estralia (2013:10) akuntansi pajak adalah menetapkan besarnya pajak terutang berdasarkan laporan keuangan yang disusun oleh perusahaan. Secara umum akuntansi perpajakan (tax accounting) adalah suatu seni mencatat, menggolongkan, mengikhtisarkan, dan menafsirkan transaksi-transaksi finansial yang dilaksanakan oleh perusahaan dengan tujuan menentukan jumlah penghasilan kena pajak yang diperoleh atau diterima dalam satu tahun pajak guna sebagai dasar penetapan beban atau pajak penghasilan yang terutang oleh perusahaan sebagai wajib pajak. Dalam hal ini wajib pajak adalah wajib pajak badan dan wajib pajak orang pribadi. Definisi lain akuntansi perpajakan yaitu salah satu cabang akuntansi yang mencatat, menangani, menghitung, menganalisa dan membuat strategi perpajakan sehubungan dengan transaksi perusahaan.

\subsection{Aktiva Tetap}

Menurut Sumarsan (2015:159), dalam akuntansi aktiva tetap adalah aktiva yang dibeli oleh perusahaan atau orang pribadi yang digunakan untuk operasional perusahaan yang memiliki nilai yang relatif tinggi, memiliki umur manfaat lebih dari satu tahun dengan nilai perolehan yang relatif tinggi dan tidak untuk diperjualbelikan. Jadi, aktiva tetap diperoleh oleh perusahaan tidak untuk diperjualbelikan, tetapi untuk operasional perusahaan. Aktiva 
yang dibeli oleh perusahaan untuk dijual kembali dinamakan persediaan dan digolong dalam aktiva lancar.

\subsection{Penyusutan}

Hery (2015:275), penyusutan adalah alokasi secara periodik dan sistematis dari harga perolehan aset selama periode-periode berbeda yang memperoleh manfaat dari penggunaan aset bersangkutan.

\subsubsection{Faktor-faktor Yang Mempengaruhi Beban Penyusutan}

Menurut Hery (2015:276-279) faktor-faktor yang mempengaruhi beban penyusutan adalah:

1. Nilai perolehan aset (asset cost), mencakup seluruh pengeluaran yang terkait dengan perolehannya dan persiapannya sampai aset dapat digunakan.

2. Nilai residu/nilai sisa (residual or salvage value), merupakan estimasi nilai realisasi pada saat aset tidak dipakai lagi.

3. Umur ekonomis (economic life), dapat diartikan sebagai suatu periode atau umur fisik di mana perusahaan dapat dimanfaatkan aset tetapnya.

4. Pola pemakaian (pattern of use), pola pemakaian ini seringkali diabadikan dalam menghitung besarnya beban penyusutan periode mengingat sulitnya dalam mengidentifikasi pola pemakaian dimaksud.

\subsubsection{Metode Penyusutan}

Menurut Herry (2015:279-290) ada beberapa metode yang berbeda untuk menghitung besarnya beban penyusutan. Dalam praktik, kebanyakan perusahaan akan memilih satu metode penyusutan dan akan menggunakannya untuk seluruh aset yang dimilikinya. Beberapa metode tersebut yaitu:

1. Berdasarkan waktu

a. Metode garis lurus (straight line method)

b. Metode pembebanan yang menurun

1) Metode jumlah angka tahun (sum of the year digit method)

2) Metode saldo menurun ganda (double declining balance method)

2. Berdasarkan penggunaan

a. Metode jam jasa (service hours method)

b. Metode Unit Produksi (productive output method)

\subsubsection{Penyusutan Berdasarkan Standar Akuntansi Keuangan}

Menurut SAK (2017), penyusutan diakui bahkan jika nilai wajar aset melebihi jumlah tercatatnya sepanjang nilai residu aset tidak melebihi jumlah tercatatnya. Perbaikan dan pemeliharaan aset tidak meniadakan keharusan untuk menyusutkan aset. Jumlah tersusutkan suatu aset ditentukan setelah dikurangi nilai residunya. Dalam praktik, nilai residu aset terkadang tidak signifikan dan oleh karena itu tidak material dalam penghitungan jumlah tersusutkan.

Manfaat ekonomik masa depan suatu aset dipakai oleh entitas terutama melalui penggunaannya. Akan tetapi, beberapa faktor lain seperti keusangan teknis, keusangan komersial, dan keausan selama aset tidak terpakai, sering mengakibatkan menurunnya manfaat ekonomik yang dapat diperoleh dari aset tersebut. Umur manfaat aset ditentukan berdasarkan kegunaan yang diperkirakan oleh entitas. Kebijakan manajemen aset dari entitas mungkin mencakup pelepasan aset setelah jangka waktu tertentu atau setelah pemakaian sejumlah proporsi tertentu dari manfaat ekonomik masa depan. Oleh karena itu, umur manfaat aset dapat lebih pendek daripada umur ekonomik aset tersebut. Estimasi umur manfaat suatu aset membutuhkan pertimbangan berdasarkan pengalaman entitas terhadap aset yang serupa. Penghapusan aktiva adalah penghapusan nilai buku suatu aktiva yang dilakukan apabila nilai buku yang tercantum tidak lagi menggambarkan manfaat dari aktiva yang bersangkutan. Penghapusan aktiva berbeda dengan penyusutan. 
Metode penyusutan yang dipilih harus digunakan secara konsisten dari periode ke periode kecuali perubahan keadaan yang memberi alasan atau dasar suatu perubahan metode. Dalam suatu periode akuntansi dimana metode penyusutan berubah, pengaruh perubahan harus dikuantifikasikan dan harus diungkapkan.

\subsubsection{Penyusutan Berdasarkan Peraturan Perpajakan}

Menurut Sumarsan (2015:166), penyusutan atau amortisasi atas pengeluaran untuk memperoleh harta, wajib pajak dapat memilih dan melakukan penyusutan atau amortisasi atas pengeluaran untuk pembelian, pendirian, penambahan, perbaikan, atau perubahan harta bukan bangunan yang masih dimiliki dan digunakan untuk mendapatkan, menagih, dan memelihara penghasilan dengan menggunakan metode garis lurus atau metode saldo menurun. Metode penyusutan atau amortisasi yang dipilih mencakup semua harta bukan bangunan harus konsisten. Dengan perkataan lain, tidak diperbolehkan menggunakan dua macam metode penyusutan atau amortisasi untuk harta bukan bangunan.

Penggolongan Aset Tetap Menurut Ketentuan Perpajakan:

\begin{tabular}{|c|c|c|c|}
\hline $\begin{array}{c}\text { Kelompok } \\
\text { Harta Berwujud }\end{array}$ & $\begin{array}{c}\text { Masa } \\
\text { Manfaat }\end{array}$ & $\begin{array}{c}\text { Tarif Penyusutan } \\
\text { Berdasarkan } \\
\text { Metode Garis Lurus }\end{array}$ & $\begin{array}{c}\text { Tarif Penyusutan } \\
\text { Berdasarkan } \\
\text { Metode Saldo Menurun }\end{array}$ \\
\hline I. Bukan Bangunan & & $25 \%$ & $50 \%$ \\
\hline Kelompok 1 & 4 Tahun & $12,5 \%$ & $25 \%$ \\
\hline Kelompok 2 & 8 Tahun & $6,25 \%$ & $12,5 \%$ \\
\hline Kelompok 3 & 16 Tahun & $5 \%$ & $10 \%$ \\
\hline Kelompok 4 & 20 Tahun & & - \\
\hline II. Bangunan & & $5 \%$ & - \\
\hline Permanen & 20 Tahun & $10 \%$ & \\
\hline Tidak Permanen & 10 Tahun & & \\
\hline
\end{tabular}

Sumber: (Waluyo:2013)

Pengelompokan jenis-jenis harta berwujud, sebagaimana Keputusan Menteri Keuangan Nomor 96/PMK.03/2009 yang berlaku sejak 1 Januari 2009.

\subsection{Koreksi Fiskal}

Perbedaan karena adanya koreksi fiskal dapat menimbulkan koreksi berupa:

1. Koreksi Positif

Koreksi ini mengakibatkan pengurangan biaya atau penambahan penghasilan yang telah diakui dalam laporan laba-rugi secara komersial, artinya laba fiskal akan lebih besar dari laba komersil.

2. Koreksi Negatif

Koreksi ini mengakibatkan penambahan biaya atau pengurangan penghasilan, artinya laba fiskal akan lebih kecil dari laba komersil.

\subsection{Penelitian Terdahulu}

Beberapa penelitian terdahulu yang penulis jadikan sebagai bahan pertimbangan dalam melakukan penelitian di CV. Samia Sejahtera. Penelitian yang dilakukan oleh Christovint 2015, tentang Evaluasi Perhitungan Penyusutan Aktiva Tetap Menurut Peraturan Perpajakan Serta Pengaruhnya Terhadap Pajak Penghasilan (PPh) Pada PT. Bank Tabungan Negara (Persero) Tbk Kantor Cabang Manado, menyatakan bahwa perhitungan penyusutan perusahaan telah sesuai dengan ketentuan perpajakan hanya saja masih terdapa kekeliruan dalam perhitungan penyusutannya sehingga menimbulkan selisih nilai perhitungan penyusutan yang dilakukan perusahaan dengan perhitungan penyusutan perpajakan. Pada penelitian yang dilakukan oleh Ajeng Citralarasati Mardjani 2015, tentang Perhitungan 
Penyusutan Aset Tetap Menurut Standar Akuntansi Keuangan dan Peraturan Perpajakan Pengaruhnya Terhadap Laporan Keuangan Pada PT. Hutama Karya Manado, menyatakan bahwa penerapan metode penyusutan yang belum konsisten dan adanya perbedaan perhitungan menurut SAK maupun peraturan perpajakan disebabkan penggunaan metode penyusutan dan ketentuan yang berlaku. Pada penelitian yang dilakukan oleh Giantino A. Ratag 2013, tentang Perencanaan Pajak Melalui Metode Penyusutan Aktiva Tetap Untuk Menghitung PPh Badan Pada PT. Bank Sulut, menyatakan bahwa perusahaan dalam menjalankan aktivitasnya belum sepenuhnya melakukan perencanaan pajak melalui metode penyusutan aktiva tetap. Pada penelitian yang dilakukan oleh Mirawati Florce Sihombing 2016, tentang Analisis Penerapan Metode Penyusutan Aktiva Tetap dan Implikasinya Terhadap Laba Perusahaan Pada PT. Manado Persada Madani, menyatakan bahwa metode penyusutan yang digunakan oleh perusahaan adalah garis lurus dan perhitungan yang dilakukan menghasilkan laba yang lebih besar dibandingkan menggunakan metode saldo menurun ganda dan jumlah angka tahun. Pada penelitian yang dilakukan oleh Samuel Mairuhu 2014, tentang Analisis Penerapan Metode Penyusutan Aktiva Tetap dan Implikasinya Terhadap Laba Perusahaan Pada Perum Bulog Divre Sulut dan Gorontalo, menyatakan bahwa dalam penyusutan aktiva tetap menggunakan metode garis lurus karena implikasinya terhadap laba lebih tinggi nilainya dibandingkan dengan menggunakan metode perhitungan saldo menurun ganda dan metode jumlah angka tahun.

\section{METODE PENELITIAN}

\subsection{Jenis Penelitian}

Penelitian ini termasuk pada jenis penelitian kualitatif deskriptif. Sujarweni (2014:5) mengatakan bahwa, penelitian dapat diklasifikasikan dalam berbagai sudut pandang jenis dan analisis data, berdasarkan tujuannya, berdasarkan metode, berdasarkan tingkat eksplanasi, dan pendekatannya.

\subsection{Waktu dan Tempat Penelitian}

Penelitian dilakukan di CV. Samia Sejahtera yang berada di Jl. Raya Manado-Bitung Kel. Sagerat Weru I Blok A No. 5 Perum Mutiara Kec. Matuari Kota Bitung. Penelitian ini dilakukan dari bulan Mei sampai dengan bulan Juni 2018.

\subsection{Metode Analisis}

Metode yang digunakan dalam penelitian ini adalah metode analisis deskriptif yaitu penelitian yang disusun dalam rangka memberikan gambaran secara sistematis tentang informasi ilmiah yang berasal dari subjek atau objek penelitian. Dalam penelitian ini peneliti mengolah dan menganalisis data dari hasil penelitian yang dilakukan pada objek penelitian dan mendeskripsikan serta menggambarikan data yang telah dikumpulkan dari objek penelitian dan menarik kesimpulan. 


\section{HASIL ANALISIS DAN PEMBAHASAN}

4.1. Hasil Analisis

4.1.1 Perhitungan Penyusutan Aktiva Tetap CV. Samia Sejahtera

CV. Samia Sejahtera

Daftar Penyusutan Aktiva Tetap

Desember 2017

\begin{tabular}{|l|r|r|r|r|r|}
\hline \multicolumn{1}{|c|}{$\begin{array}{c}\text { Jenis } \\
\text { Aktiva }\end{array}$} & $\begin{array}{c}\text { Harga } \\
\text { Perolehan }\end{array}$ & $\begin{array}{c}\text { Ak. Peny. s/d } \\
\text { Tahun 2016 }\end{array}$ & $\begin{array}{c}\text { Biaya } \\
\text { Penyusutan } \\
\text { Tahun 2017 }\end{array}$ & $\begin{array}{c}\text { Ak. Peny. s/d } \\
\text { Tahun 2017 }\end{array}$ & Nilai Buku \\
\hline Tanah & $143,700,000.00$ & - & - & & $143,700,000.00$ \\
\hline Bangunan & $216,690,000.00$ & $43,338,000.00$ & $10,834,500.00$ & $54,172,500.00$ & $162,517,500.00$ \\
\hline Kendaraan & $510,600,000.00$ & $158,160,000.00$ & $51,060,000.00$ & $209,220,000.00$ & $301,380,000.00$ \\
\hline Peralatan & $1,145,938,700.00$ & $447,455,150.00$ & $123,511,965.00$ & $570,967,115.00$ & $574,971,585.00$ \\
\hline Inventaris & $44,709,700.00$ & $22,295,840.00$ & $8,941,940.00$ & $31,237,780.00$ & $13,471,920.00$ \\
\hline Total & $\mathbf{2 , 0 6 1 , 6 3 8 , 4 0 0 . 0 0}$ & $\mathbf{6 7 1 , 2 4 8 , 9 9 0 . 0 0}$ & $\mathbf{1 9 4 , 3 4 8 , 4 0 5 . 0 0}$ & $\mathbf{8 6 5 , 5 9 7 , 3 9 5 . 0 0}$ & $\mathbf{1 , 1 9 6 , 0 4 1 , 0 0 5 . 0 0}$ \\
\hline
\end{tabular}

Sumber: Data Internal CV. Samia Sejahtera 2017

Dari data penyusutan aktiva tetap dapat dilihat total keseluruhan penyusutan aktiva tetap CV. Samia Sejahtera pada Desember 2017, harga perolehan sebesar Rp2.061.638.400,00, akumulasi penyusutan sampai dengan tahun 2016 sebesar Rp671.248.990,00, biaya penyusutan tahun 2017 sebesar Rp194.348.405,00, akumulasi penyusutan sampai dengan tahun 2017 sebesar Rp865.597.395,00 dan nilai buku tahun 2017 sebesar Rp1.196.041.005,00.

\subsubsection{Laporan Laba Rugi CV. Samia Sejahtera}

\section{Samia Sejahtera}

Laporan Laba Rugi

\section{Untuk Periode Yang Berakhir 31 Desember 2017}

\section{PENDAPATAN}

Penjualan

(dalam rupiah)

\section{HARGA POKOK PENJUALAN}

Persediaan Awal Bahan Baku

Pembelian Bahan Baku

Total bahan baku siap Digunakan

Persediaan Akhir Bahan Baku

$39,200,000.00$

$305,091,000.00$

$344,291,000.00$

$37,200,300.00$

Biaya Pemakaian Bahan

Tenaga Kerja Langsung

BOP:

Biaya BBM Kendaraan Operasional

Biaya Perbaikan Mesin

Biaya Perawatan Mesin

Biaya Penyusutan Mesin

Biaya Penyusutan Kendaraan

Total Biaya Overhead Pabrik
$968,002,100.00$
$307,090,700.00$

$167,550,000.00$

$3,225,000.00$

$2,540,000.00$

$6,520,000.00$

$123,511,965.00$

$51,060,000.00$ 
Total Biaya Produksi

Persediaan Barang Jadi (awal)

Persediaan Barang Jadi (akhir)

Harga Pokok Penjualan (HPP)

Laba Kotor

\section{BEBAN OPERASIONAL}

Gaji Pegawai

Beban Jamuan Tamu

Beban Perlengkapan Kantor

Beban Air

Beban Telepon

Beban Listrik

Beban Penyusutan Gedung Kantor

Beban Penyusutan Inventaris

Beban Lain

Total Beban Operasional

Laba Operasional

\section{PENDAPATAN DAN KEUNTUNGAN}

\section{LAIN-LAIN}

Pendapatan Bunga Bank

Pendapatan Sewa

Keuntungan Atas Penjualan Investasi

Total Pendapatan dan Keuntungan Lain-

lain

\section{BEBAN DAN KERUGIAN LAIN-LAIN}

Beban Bunga

Beban Adm Bank

Total Beban dan Kerugian Lain-lain

Laba Sebelum Pajak Penghasilan

Pajak Penghasilan

Laba Bersih
Beban Entertaimen

Sumber: Data Internal CV. Samia Sejahtera 2017
$661,497,665.00$

$83,500,000.00$

$\underline{92,500,000.00}$

$\underline{652,497,665.00}$

$315,504,435.00$

$153,700,000.00$

$2,370,000.00$

$740,000.00$

$1,450,000.00$

$2,400,000.00$

$25,700,000.00$

$10,834,500.00$

$8,941,940.00$

$2,750,000.00$

$612,000.00$ $\underline{209,498,440.00}$

$106,005,995.00$

$730,000.00$

$33,000,000.00$

$\underline{440,000.00}$

$730,000.00$ $\underline{33,440,000.00}$

73,295,995.00

$18,323,998.75$

$54,971,996.25$

Dari laporan laba rugi CV. Samia Sejahtera dapat dilihat laba bersih yang diperoleh oleh perusahaan selama satu periode akuntansi adalah Rp54.971.996,25. 


\title{
4.2 Pembahasan
}

4.2.1 Perhitungan Penyusutan Aktiva Tetap Menurut Standar Akuntansi Keuangan Pada CV. Samia Sejahtera

\author{
CV. Samia Sejahtera
}

Daftar Penyusutan Aktiva Tetap Menurut Standar Akuntansi Keuangan Desember 2017

\begin{tabular}{|l|r|r|r|r|c|}
\hline \multicolumn{1}{|c}{$\begin{array}{c}\text { Jenis } \\
\text { Aktiva }\end{array}$} & $\begin{array}{c}\text { Harga } \\
\text { Perolehan }\end{array}$ & $\begin{array}{c}\text { Ak. Peny. s/d } \\
\text { Tahun 2016 }\end{array}$ & $\begin{array}{c}\text { Biaya } \\
\text { Penyusutan } \\
\text { Tahun 2017 }\end{array}$ & $\begin{array}{c}\text { Ak. Peny. s/d } \\
\text { Tahun 2017 }\end{array}$ & Nilai Buku \\
\hline Tanah & $143,700,000.00$ & - & - & & $143,700,000.00$ \\
\hline Bangunan & $216,690,000.00$ & $43,338,000.00$ & $10,834,500.00$ & $54,172,500.00$ & $162,517,500.00$ \\
\hline Kendaraan & $510,600,000.00$ & $158,160,000.00$ & $46,260,000.00$ & $204,420,000.00$ & $306,180,000.00$ \\
\hline Peralatan & $1,145,938,700.00$ & $447,455,150.00$ & $120,595,298.32$ & $568,050,448.32$ & $577,888,251.68$ \\
\hline Inventaris & $44,709,700.00$ & $22,295,840.00$ & $7,886,115.00$ & $30,181,955.00$ & $14,527,745.00$ \\
\hline Total & $\mathbf{2 , 0 6 1 , 6 3 8 , 4 0 0 . 0 0}$ & $\mathbf{6 7 1 , 2 4 8 , 9 9 0 . 0 0}$ & $\mathbf{1 8 5 , 5 7 5 , 9 1 3 . 3 2}$ & $\mathbf{8 5 6 , 8 2 4 , 9 0 3 . 3 2}$ & $\mathbf{1 , 2 0 4 , 8 1 3 , 4 9 6 . 6 8}$ \\
\hline
\end{tabular}

Sumber: Data Olahan 2018

Dari data penyusutan aktiva tetap dapat dilihat total keseluruhan penyusutan aktiva tetap CV. Samia Sejahtera pada Desember 2017, harga perolehan sebesar Rp2.061.638.400,00, akumulasi penyusutan sampai dengan tahun 2016 sebesar Rp671.248.990,00, biaya penyusutan tahun 2017 sebesar Rp185.575.913,32, akumulasi penyusutan sampai dengan tahun 2017 sebesar Rp856.824.903,32 dan nilai buku tahun 2017 sebesar Rp1.204.813.496,68.

\subsubsection{Perhitungan Penyusutan Aktiva Tetap Menurut Peraturan Perpajakan} Pada CV. Samia Sejahtera

$$
\text { CV. Samia Sejahtera }
$$

Daftar Penyusutan Aktiva Tetap Menurut Peraturan Perpajakan

Desember 2017

\begin{tabular}{|l|c|c|c|c|c|}
\hline $\begin{array}{c}\text { Jenis } \\
\text { Aktiva }\end{array}$ & $\begin{array}{c}\text { Harga } \\
\text { Perolehan }\end{array}$ & $\begin{array}{c}\text { Ak. Peny. s/d } \\
\text { Tahun 2016 }\end{array}$ & $\begin{array}{c}\text { Biaya } \\
\text { Penyusutan } \\
\text { Tahun 2017 }\end{array}$ & $\begin{array}{c}\text { Ak. Peny. s/d } \\
\text { Tahun 2017 }\end{array}$ & Nilai Buku \\
\hline Tanah & $143,700,000.00$ & - & & & - \\
\hline Bangunan & $216,690,000.00$ & $43,338,000.00$ & $10,834,500.00$ & $54,172,500.00$ & $143,700,000.00$ \\
\hline Kendaraan & $510,600,000.00$ & $158,160,000.00$ & $63,825,000.00$ & $221,985,000.00$ & $288,615,000.00$ \\
\hline Peralatan & $1,145,938,700.00$ & $447,455,150.00$ & $77,367,337.50$ & $524,822,487.50$ & $621,116,212.50$ \\
\hline & & & & & \\
Inventaris & $44,709,700.00$ & $22,295,840.00$ & $5,588,712.50$ & $27,884,552.50$ & $16,825,147.50$ \\
\hline Total & $\mathbf{2 , 0 6 1 , 6 3 8 , 4 0 0 . 0 0}$ & $\mathbf{6 7 1 , 2 4 8 , 9 9 0 . 0 0}$ & $\mathbf{1 5 7 , 6 1 5 , 5 5 0 . 0 0}$ & $\mathbf{8 2 8 , 8 6 4 , 5 4 0 . 0 0}$ & $\mathbf{1 , 2 3 2 , 7 7 3 , 8 6 0 . 0 0}$ \\
\hline
\end{tabular}

Sumber: Data Olahan 2018

Dari data penyusutan aktiva tetap dapat dilihat total keseluruhan penyusutan aktiva tetap CV. Samia Sejahtera pada Desember 2017, harga perolehan sebesar Rp2.061.638.400,00, akumulasi penyusutan sampai dengan tahun 2016 sebesar Rp671.248.990,00, biaya penyusutan tahun 2017 sebesar Rp157.615.550,00, akumulasi 
penyusutan sampai dengan tahun 2017 sebesar Rp828.864.540,00 dan nilai buku tahun 2017 sebesar Rp1.232.773.860,00.

4.2.3 Perbandingan Perhitungan Penyusutan Aktiva Tetap Menurut Standar Akuntansi Keuangan dan Peraturan Perpajakan Pada CV. Samia Sejahtera

CV. Samia Sejahtera

Perbandingan Perhitungan Penyusutan Aktiva Tetap

Menurut Standar Akuntansi Keuangan dan Peraturan Perpajakan

\begin{tabular}{|c|c|c|c|}
\multicolumn{2}{|c|}{ (dalam rupiah) } \\
\hline \multirow{2}{*}{ Tahun } & \multicolumn{2}{|c|}{ Nilai Penyusutan } & \multirow{2}{*}{$\begin{array}{c}\text { Selisih Nilai } \\
\text { Penyusutan }\end{array}$} \\
\cline { 2 - 3 } & Perusahaan & Pajak & $36,732,855.00$ \\
\hline
\end{tabular}

Sumber: Data Olahan 2018

Data diatas menunjukkan perbandingan nilai penyusutan menurut Perusahaan 2017 sebesar Rp194.348.405,00 sedangkan menurut Peraturan Perpajakan tahun 2017 sebesar Rp.157.615.550,00 maka diperoleh selisih nilai penyusutan sebesar Rp.36.732.855,00. Perhitungan penyusutan menurut Perusahaan menunjukkan beban penyusutan yang lebih besar dibandingkan dengan perhitungan penyusutan menurut Peraturan Perpajakan dan diperoleh selisih nilai penyusutan yang dapat mengurangi biaya atau penambahan penghasilan yang telah diakui dalam laporan laba rugi secara komersial, artinya laba fiskal akan lebih besar dari laba komersil.

PPh CV. Samia Sejahtera

CV. Samia Sejahtera

Perbandingan Perhitungan Pajak Penghasilan (PPh)

\begin{tabular}{|c|c|c|c|}
\hline \multirow[b]{2}{*}{ Tahun } & \multicolumn{2}{|c|}{$\mathbf{P P h}$} & \multirow{2}{*}{$\begin{array}{l}\text { Selisih Nilai } \\
\text { Penyusutan }\end{array}$} \\
\hline & Perusahaan & Paiak & \\
\hline 2017 & $18,323,750.00$ & $27,507,250.00$ & $9,183,500.00$ \\
\hline
\end{tabular}

Sumber: Data Olahan 2018

Data diatas menunjukkan perbandingan nilai Pajak Penghasilan menurut Perusahaan tahun 2017 sebesar Rp18.323.750,00 sedangkan menurut Peraturan Perpajakan tahun 2017 sebesar Rp27.507.250,00 maka diperoleh selisih nilai penyusutan sebesar Rp9.183.500,00. Perhitungan Pajak Penghasilan (PPh) menurut Perusahaan menunjukkan Pajak Penghasilan $(\mathrm{PPh})$ yang lebih kecil dibandingkan dengan perhitungan Pajak Penghasilan ( $\mathrm{PPh}$ ) menurut Peraturan Perpajakan.

Dalam hasil penelitian pada CV. Samia Sejahtera, dapat dilihat bahwa perusahaan telah membuat laporan laba/rugi yang sesuai dengan Standar Akuntansi Keuangan tapi belum memegang prinsip undang-undang perpajakan. Hal ini membuat sistem pembayaran pajak jadi terganggu, akan lebih baik jika dalam laporan laba-rugi juga dimasukan data koreksi fiskal positif seperti yang akan dipaparkan berikut ini. Dalam laporan laba/rugi perusahaan yang harus dilakukan penyesuaian, di antaranya:

1. Biaya Jamuan Tamu sebesar Rp2.370.000,00

2. Biaya Entertainment sebesar Rp2.750.000,00

3. Biaya Lain sebesar Rp612.000,00

Karena perusahaan CV. Samia Sejahtera tidak ada lampiran daftar nominatif maka Biaya Jamuan Tamu sebesar Rp2.370.000,00, Biaya Entertainment sebesar Rp2.750.000,00 dan Biaya Lain sebesar Rp612.000,00 sebaiknya dikoreksi fiskal positif agar perusahaan tidak mendapat resiko saat pemeriksaan dari fiskus. Jadi, dalam koreksi fiskal akun biaya/beban jamuan tamu, biaya/beban entertainment dan biaya/beban lain dalam laporan laba-rugi komersial tersebut harus dikoreksi positif sesuai dengan jumlah biaya-biaya tersebut. 


\section{Laba Bersih Sebelum Pajak Penghasilan \\ Menurut SAK}

$=\mathbf{R p 7 3 . 2 9 5 . 9 9 5 , 0 0}$

Koreksi Fiskal Positif:

a. Biaya Jamuan Tamu sebesar Rp2.370.000,00

b. Biaya Entertainment sebesar Rp2.750.000,00

c. Biaya Lain sebesar Rp612.000,00

Jumlah Koreksi Fiskal Positif

Laba Sebelum Pajak Penghasilan Menurut

Fiskal (Laba Fiskal)

$=\underline{\operatorname{Rp5} .732 .000,00+}$

Jadi berdasarkan data koreksi fiskal yang diperoleh, diketahui bahwa laba sebelum pajak menurut akuntansi dari CV. Samia Sejahtera adalah sebesar Rp73.295.995,00 kemudian dilakukan koreksi fiskal positif sebesar Rp5.732.000,00 yang terdiri dari Biaya/beban Jamuan Tamu sebesar Rp2.370.000,00 ; Biaya/beban Entertainment sebesar Rp2.750.000,00 dan Biaya/beban Lain sebesar Rp612.000,00.

Koreksi positif tersebut akan mengakibatkan bertambahnya laba sebelum pajak menurut akuntansi dari CV. Samia Sejahtera yang berjumlah Rp73.295.995,00 bertambah sejumlah koreksi fiskal positif yaitu Rp5.732.000,00 menjadi laba sebelum pajak menurut fiskal (laba fiskal) sejumlah Rp79.027.995,00.

\begin{tabular}{lcc}
\multicolumn{1}{c}{ Keterangan } & $\begin{array}{c}\text { CV. Samia Sejahtera } \\
\text { Perbandingan PPh Terutang } \\
\text { Pembukuan Perusahaan }\end{array}$ & Peraturan Perpajakan \\
\hline Laba/Rugi Sebelum Pajak & $73,295,995.00$ & $73,295,995.00$ \\
Biaya Penyusutan & - & $36,732,855.00$ \\
Laba Sebelum Pajak Sesudah Biaya & & \\
Penyusutan & $73,295,995.00$ & $110,028,850.00$ \\
Koreksi Fiskal Lain & - & $5,732,000.00$ \\
Laba Sebelum Pajak & $73,295,995.00$ & $115,760,850.00$ \\
Beban PPh/PPh Terutang & $18,323,750.00$ & $28,940,000.00$ \\
\hline
\end{tabular}

Sumber: Data Olahan 2018

Dengan adanya koreksi fiskal maka laba sebelum pajak menurut Perusahaan sebesar Rp18.323.750,00 seharusnya berjumlah Rp28.940.000,00. Dari data di atas terlihat bahwa perusahaan dalam melakukan pembayaran PPh untuk tahun 2017 sebesar Rp10.616.250,00.

\section{KESIMPULAN DAN SARAN}

\subsection{Kesimpulan}

Berdasarkan hasil penelitian dan pembahasan yang telah dilakukan pada CV. Samia Sejahtera, maka dapat diambil beberapa kesimpulan sebagai berikut:

1. Penerapan metode perhitungan penyusutan aktiva tetap telah sesuai dengan ketentuan Standar Akuntansi Keuangan, tetapi masih terdapat kekeliruan pada perhitungan penyusutannya.

2. Penerapan metode penyusutan aktiva tetap menurut ketentuan Peraturan Perpajakan seharusnya dilakukan oleh pihak perusahaan untuk keperluan perpajakan. Dalam melakukan perhitungan penyusutan aktiva tetap menurut Peraturan Perpajakan, perusahaan harus menggunakan Peraturan Menteri Keuangan Nomor 96/PMK.03/2009 baik penggolongan aktiva tetapnya maupun penentuan tarif penyusutan dan masa manfaat dari suatu aktiva tetap perusahaan.

3. Dengan adanya perbedaan perhitungan penyusutan aktiva tetap, dimana beban penyusutan menurut Standar Akuntansi Keuangan menunjukkan nilai yang lebih besar dibandingkan beban penyusutan menurut Peraturan Perpajakan, maka ditemukan adanya koreksi fiskal positif yang mengakibatkan adanya pengurangan biaya yang telah diakui dalam laporan 
laba rugi komersial. Dengan adanya pengurangan pengakuan biaya tersebut dapat berdampak pada penambahan Pajak Penghasilan (PPh). Nilai PPh CV. Samia Sejahtera tahun 2017 sebesar Rp18.323.750,00 sedangkan nilai PPh CV. Samia Sejahtera menurut fiskal Rp28.940.000,00 jadi ada selisih sebesar Rp10.616.250,00.

\subsection{Saran}

Dari hasil kesimpulan diatas maka diberikan saran untuk dapat menjadi bahan pertimbangan dalam penyusunan laporan keuangan perusahaan.

1. Sebaiknya dalam menghitung penyusutan aktiva tetap harus dibutuhkan ketelitian agar nilai penyusutan yang dihasilkan lebih efisien dan benar-benar sesuai dengan yang sebenarnya.

2. Dengan adanya perbedaan pengakuan biaya, sebaiknya perusahaan mengelompokkan aktiva tetap sesuai dengan Peraturan Menteri Keuangan Nomor 96/PMK.03/2009, agar lebih mudah untuk menghitung beban penyusutan.

3. Dengan menghitung beban penyusutan sesuai dengan ketentuan yang berlaku dalam Peraturan Perpajakan dengan benar, maka perusahaan dapat membayar Pajak Penghasilan $(\mathrm{PPh})$ sesuai dengan ketentuan Peraturan Perpajakan.

\section{DAFTAR PUSTAKA}

Agoes, Sukrisno. dan Estralita. 2013. Akuntansi Perpajakan. Edisi 3. Salemba Empat, Jakarta.

Christovint. 2015. Evaluasi Perhitungan Penyusutan Aktiva Tetap Menurut Peraturan Perpajakan Serta Pengaruhnya Terhadap Pajak Penghasilan (PPh) Pada PT. Bank Tabungan Negara (Persero) Tbk Kantor Cabang Manado. Skripsi.Universitas Sam Ratulangi (UNSRAT). Manado.

Hery. 2015. Pengantar Akuntansi, Comprehensive Edition. Penerbit PT Grasindo, Anggota Ikapi. Jakarta.

Ikatan Akuntan Indonesia (IAI). 2016b. Aset Tetap. Pernyataan Standar Akuntansi Keuangan No.16. (Revisi 2015). DSAK-IAI. Jakarta.

Mairuhu, Samuel. 2014. Analisis Penerapan Metode Penyusutan Aktiva Tetap dan Implikasinya Terhadap Laba Perusahaan pada Perum Bulog Divre Sulut dan Gorontalo. Jurnal EMBA 2(4): 404-412.

Mardiasmo, 2018. Perpajakan, Edisi Terbaru 2018. Penerbit Andi. Yogyakarta.

Mardjani, C. A. 2015. Perhitungan Penyusutan Aset Tetap Menurut Standar Akuntansi Keuangan Dan Peraturan Perpajakan Serta Pengaruhnya Terhadap Laporan Keuangan Pada PT. Hutama Karya Manado. Skripsi. Universitas Sam Ratulangi (UNSRAT) Manado.

Pohan, A. C. 2017. Manajemen Perpajakan: Strategi Perencanaan Pajak dan Bisnis, Edisi Revisi. Penerbit Gramedia. Jakarta.

Pontoh, Winston. 2013. Akuntansi : Konsep dan Aplikasi. Halaman Moeka. Jakarta Barat.

Rahman, Arif. 2013, Panduan Akuntansi dan Perpajakan. Jakarta: Transmedia.

Ratag, A. G. 2013. Perencanaan Pajak Melalui Metode Penyusutan Aktiva Tetap Untuk Menghitung PPh Badan Pada PT. Bank Sulut. Jurnal EMBA 1(3): 950-958.

Sihombing, F. M. 2016. Analisis Penerapan Metode Penyusutan Aktiva Tetap dan Implikasinya Terhadap Laba Perusahaan Pada PT. Manado Persada Madani. Jurnal EMBA 4(2): 632-639.

Sujarweni, V. W. 2015. Sistem Akuntansi. Pustaka Baru Press, Yogyakarta. . 2014. Metodologi Penelitian. PUSTAKA BARU PRESS.

Sumarsan, Thomas. 2015. Perpajakan Indonesia. Penerbit PT Indeks. Jakarta. Waluyo. 2013. Perpajakan Indonesia. Edisi 11 - Buku 1. Salemba Empat. Jakarta. 